\title{
Towards a Morph-syntactic Typology of Split Intransitivity
}

\author{
Wenchao Li*, Alita \\ Department of Japanese Studies, School of International Studies, Zhejiang University, China
}

Copyright $\bigcirc 2016$ by authors, all rights reserved. Authors agree that this article remains permanently open access under the terms of the Creative Commons Attribution License 4.0 International License

\begin{abstract}
This paper analyses the split intransitivity by introducing data from Japanese and Mongolian. The finding reveals that Japanese split intransitivity links to postposition selection, i.e. unergative motion verbs describe processes with a durative motion event and thus are likely to yield directional postpositions or a route with an endpoint. Unaccusative verbs, on the other hand, indicate a punctual motion event and therefore often occur with locative postpositions. Intransitives further split in lexicalisation, i.e. Japanese unergative verbs tend to convey the MANNER of motion while unaccusative verbs appear to favour the PATH of motion. Mongolian seems to render the path in the main verb, leaving manner to be encoded in an optional constituent, i.e. a converbal construction. The combination of converbal construction is restricted to [non-scale change morphemes + totally closed-scale change morphemes] and [non-scale change morphemes + lower closed-scale morphemes]. Essentially, unergative verbs can be non-scale change morpheme or totally open-scale morpheme, contributing to the manner of motion. Unaccusative verbs can be totally closed-scale, or upper closed-scale, or lower closed-scale morpheme, denoting the path of motion.
\end{abstract}

Keywords Split Intransitivity, Unaccusative, Unergative, Morpho- syntax, Japanese, Mongolian

\section{Introduction}

Split intransitivity refers to a phenomenon that different intransitive verbs in certain language may display different linguistic behaviours. Intransitives could split in syntax or semantics.

Following the Unaccusativity Hypothesis (Perlmutter [22]), intransitive verbs can be subcategorised into two types: unaccusatives and unergatives. An unaccusative verb has a syntactic external argument that is not the semantic agent. Semantically, the subject of an unaccusative verb is similar to the direct object of a transitive verb. For instance, fall, rise. An unergative verb semantically has an agent argument, such as run, walk.

The syntactic distinctions of the two lies in that, unaccusatives have an internal argument (1a) whilst unergatives have an external argument (1b).

(1) Syntactic distinction
a. Unergative:
NP [VP V]
b. Unaccusative:
[VP V NP]

A semantic characteristic regarding split intransitivity is their concurrences with predicates, i.e. unergativity is likely to correlate with 'agentivity' and unaccusativity with patient-hood (Dowty [6]).

(2) Semantic distinction
a. Unergative:
Agentivity
b. Unaccusative:
Patient-hood

Split intransitivity has been studied a good deal within European languages. The central point for cross-linguistic interests is the diagnostics of unaccusativity/unergativity. Various theories have been devoted to pursue a satisfactory diagnostic, e.g. the Universal Alignment Hypothesis (Perlmutter \& Postal [23]). Recently, Sorace [25] proposes 'Auxiliary Selection Hierarchy', which appears a welcome one, i.e. unaccusative verbs are likely to select BE whilst unergative verbs tend to choose HAVE. Table 1 is Sorace's Auxiliary Selection Hierarchy.

Table 1. Auxiliary Selection Hierarchy

\begin{tabular}{|c|c|}
\hline Change of location & come, arrive, leave, fall \\
\hline Change of state & $\begin{array}{l}\text { rise, become, decay, die, be } \\
\text { born, happen ... }\end{array}$ \\
\hline Continuation of a pre-existing state & $\begin{array}{l}\text { stay, remain, last, survive, } \\
\text { persist ... }\end{array}$ \\
\hline Existence of state & $\begin{array}{l}\text { be, belong, sit, seem, be } \\
\text { useful, depend on } . .\end{array}$ \\
\hline Uncontrolled process & $\begin{array}{l}\text { tremble, catch on, skid, cough, } \\
\text { rumble, rain ... }\end{array}$ \\
\hline Controlled process (motional) & swim, run, walk . . . \\
\hline Controlled process (non-motional) & work, play, talk . \\
\hline
\end{tabular}

Another pathway comes from lexical semanticians who contend that different verbs have different meanings, which in turn results in various lexical semantic representations as well as argument structure realisation. This comment 
inspires a projectionist approach and representative work includes Hale \& Keyser [10, 11], Levin \& Rappaport Hovav [17-19]. For instance, in English resultatives, direct object NP must be governed by the verb (Levin \& Rappaport Hovav [19]), c.f. (3).

(3) a. The bottle broke open. (unaccusative) b. *John shouted hoarse. (unergative)

Legendre [15-16] presents a universal set-inclusion hierarchy of eventive features based on the optimality-theoretic, as in (4).

(4) Universal set-inclusion hierarchy
(a) Inherent volitionality
(b) State
(c) Directed change
(d) Telicity
(e) Inhomogeneity
(f) Inherent displacement

There is another line of research that bears significance to the study of lexicalisation, arguing in favour of constructional factors. Remarkable works in this field are Arad [1], Borer [5], van Hout [26, 27], McClure [21]. The constructional approach considers the unaccusativity and unergativity of verbs are not solely lexical properties, but are derived from the syntactic configurations of where verbs appear or how they are combined. The challenge remains, however, cross-linguistically, some verbs displays inconsistent behaviours, e.g. 'blush' is unaccusative in Italian whilst unergative in Dutch. Intra-linguistically, continuare 'continue' can take both auxiliary essere/E 'be' and auxiliary avere/A 'have' in Italian (Legendre [16]). It appears that split intransitivity within or across languages is far from being a clear-cut case.

Split intransitivity within Altaic languages remains unexplored. For instance, Japanese and Mongolian. A large number of unaccusative/unergative verbs co-existed in the two languages, c.f. (5).

(5) Japanese

a. Mado ga ware-ta. (unaccusative, inchoative) window NOM break $_{\text {intr }}$-PAST

'The window broke.'

$$
\begin{array}{lll}
\text { b. Taro ga } & \text { nai-ta. } & \text { (unergative) } \\
\text { Taro NOM } & \text { cry-PAST } & \\
\text { 'Taro cried.' } &
\end{array}
$$

(5a) is anticausativisation. Japanese unaccusative verbs usually accompany transitive alternations, as in (6).

(6) Taro wa mado wo wa-tta. (causative) Taro TOP $^{1}$ window ACC break $_{\text {tran. }}$-PAST 'Taro broke the window.'

Inchoative (5a) and causative (6) alternation in Japanese is mainly facilitated in morphological level: a morpheme that indicates intransitive and transitive properties is added

\footnotetext{
${ }^{1}$ TOP: topic; NOM: nominative; ACC: accusative; PAST: past tense.
}

to the verb stem, e.g. kowa-s-(r)u/kowa-re-ru and kir-0/-(r)u/kir-e-ru. In fact, Japanese inchoative/causative alternation presents two variations.

Anticausativisation: The object changes in terms of the property of the object itself. The transitive verb comes to bear an intransitive function via identifying the object and causer.

$$
\begin{aligned}
& x \text { CONTROL }\left[\begin{array}{lll}
y & \text { BECOME } & \left.\left.\left[\begin{array}{lll}
y & \mathrm{BE} & \mathrm{AT}-z
\end{array}\right]\right]\right]
\end{array}\right. \\
& x=y \quad \text { CONTROL } \quad\left[\begin{array} { l l l l } 
{ y } & { \text { BECOME } }
\end{array} \left[\begin{array}{ll}
y & \mathrm{BE}
\end{array}\right.\right. \\
& \text { AT- } z \text { ]]] }
\end{aligned}
$$

e.g. waru/wareru ; yaburu/yabureru

Decausativisation: The object changes in terms of external factors. The intransitivisation affix '-ar-' suppresses the causer in semantic structure, without projection to the syntactical structure. Through this manipulation, transitive verbs come to have an intransitive function.

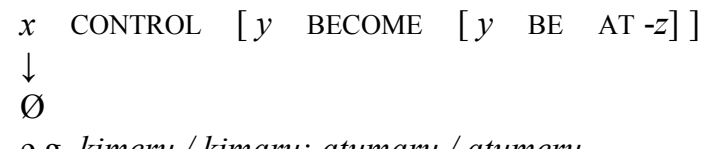

e.g. kimeru / kimaru; atumaru / atumeru (Based upon Kageyama [9])

Split intransitivity in Japanese further extends to motion construction. It occurs that unergative verbs and unaccusative verbs show a very different preference:
(7) a. Taroo a eki ni i-tta. (unaccusative) Taroo NOM station DAT go-PAST 'Taroo went to the station.'
b. *Taroo ga eki ni arui-ta. (unergative) ill-formed
Taroo NOM station DAT walk-PAST
'Taroo walked to the station.'
c. Taroo ga arui-ta. (unergative) well-formed
Taroo NOM walk-PAST
'Taroo walked.'

In (7a), the verb $i k u$ (past tense is ' $i t t a ')$ is unaccusative. It renders the path of the motion: go to the station. In (7b), aruku denotes the manner of 'walk'; the manner verb aruku alone cannot render a motion expression. Unergative verbs tend to yield the MANNER of motion while unaccusative verbs tend to convey the PATH of motion.

Turning to Mongolian, unaccusative and unergatives verbs are illustrated in (8) and $(9)^{2}$ :

(8) Mongolian unaccusative verbs

$$
\begin{aligned}
& \text { хагарах 'breakintr.' } \\
& \text { тасарах 'cutintr.' } \\
& \text { эвдэрэх 'breakintr.' }
\end{aligned}
$$

2 There are three writing systems in Mongolian: Todo Bicig (Xinjiang area), Traditional Mongolian alphabet (Hudum) (Inner Mongolia) and Cyrillic Mongolian (Outer Mongolia). In this study, Cyrillic Mongolian was adopted.

A list of Mongolian Cyrillic alphabet is provided at the end of the paper. 
шатах 'burnintr.'

хүрэх 'arrive'

(9) Mongolian unergative verbs

$\begin{array}{ll}\text { Уйлах } & \text { 'cry' } \\ \text { ажиллах } & \text { 'work' } \\ \text { біжиглэх } & \text { 'dance' }\end{array}$

The equivalent constructions of (5) are given in (10):

(10) Mongolian

a. шил нагарав. (unaccusative, inchoative)
window-NOM break ${ }_{\text {intr-PAST }}$
'The window broke.'
b. тар oo уйлaв. (unergative)
Taro-NOM cry-PAST
'Taro cried.'

The manner of motion/action in Mongolian is usually realised via a converbal construction:

(11) a. сэмэрхэн ойртох 'crawl towards' b. avaad gargax 'take out'

In (11), the second constituent, which renders the PATH, is the core of the motion/action expression. The manner/means is conveyed by a converb (the first constituent).

The above are preliminary illustrations that inspire us to investigate the phenomenon of Altaic split intransitivity in more depth. The analysis will follow the 'scale structure' framework to account for the similarities as well as distinctions of the two languages. The data for Modern Japanese is from the corpus of Balanced Corpus of Modern Written Japanese by National Institute for Japanese language and linguistics. The data for Modern Mongolian use 'hand-made examples'. Two Mongolian native speakers from different parts of Mongolia judge all data.

The paper is mapped out as follows: Section 2 introduces the framework that is adopted in this study: scale structure. Section 3 discusses the semantic representations in terms of motion event, delving into the split regarding postposition selections. Section 4 turns to Mongolian, exploring the split regarding motion expression. Section 5 draws some general conclusions.

\section{Framework: Scalar Structure}

This paper takes the scalar structure theory as the framework. The adoption of scale in linguistic track can be traced back to 70 years ago (Sapir [24]). Later, it was adopted in formal semantics (Bolinger [4]). It was not until 1990s that scale was started being introduced to syntax (Hay et al. [8]). Recently, lexical semantians apply it to adjectives, verbs, etc. (e.g. Kennedy and McNally [14]; Kennedy and Levin [13]). A scale is constituted of a set of degrees on a particular dimension (e.g. cost, depth, height, temperature), with an ordering relation. The dimension represents an attribute of an entity, with the degrees indicating the possible values of this attribute (Kennedy and McNally [14]).

\section{Split Intransitivity in Japanese}

\subsection{Split Intransitivity Regarding Motion Event}

With the framework of scale structure highlighted, this section proceeds by posing the questions of how motion constructions might reflect Japanese split intransitivity.

To begin with, motion verbs in Japanese can be divided into five groups based upon their scale strcture: (a) totally open-scale morphemes; (b) totally closed-scale morphemes; (c) upper closed-scale morphemes; (d) lower closed-scale morphemes; (e) non-scale change morphemes. The classification is demonstrated in (12):

(12) a. Totally open-scale morphemes:

kuguru 'pass through', yokeru 'ward off', mukau 'go toward', sakarau 'go against', zureru 'slip out', utsuru 'shift', kayou 'ply', narabu 'queue up', mawaru 'around'

b. Totally closed-scale morphemes:

tsuku 'arrive', itaru 'get to', todoku 'reach', noru 'get on', koeru 'transcend', oriru 'descend', tooru 'through', sugiru 'past', yokogiru 'cross', deru 'exit', hairu 'entre'

c. Upper closed-scale morphemes:

modoru 'return', kuru 'come', wataru 'cross', kaeru 'return', heru 'pass', chikazuku 'approach', kudaru 'descend', noboru 'climb'

\section{d. Lower closed-scale morphemes:}

meguru 'move around', iku 'go', sou 'go along', yoru 'approach', hanareru 'leave', noku 'move backward', kasumeru 'flit', saru 'go away', sagaru 'descend', agaru 'ascend'

\section{e. Non-scale change morphemes:}

aruku 'walk', ayumu 'walk', oyogu 'swim', hashiru 'run', haseru 'run', kakeru 'run', hau 'crawl', suberu 'slide', odoru 'dance', korogaru 'tumble', haneru 'jump', mau 'dance', moguru 'dive', samayou 'wander', tobu 'fly'

The distribution of unergatives and unaccusatives is given in (13):

(13) a. Totally open-scale morpheme: unaccusative V, denoting the path of motion

b. Totally closed-scale morpheme: unaccusative V, denoting the path of motion

c. Upper closed-scale morpheme: unaccusative V, denoting the path of motion

d. Lower closed-scale morpheme: unaccusative V, denoting the path of motion

e. Non-scale change morpheme: unergative V, conveying the manner of motion 
Totally closed-scale morphemes as well as upper closed-scale morpheme have specific goals. Therefore they can take $n i$ 'to', $e$ 'toward' case particles. On the other hand, non-scalar change morpheme, totally open-scale morphemes and lower closed-scale morpheme do not have inherent endpoints. When expressing a motion, they would have to employ a boundary marker made 'until' to indicate the endpoint of motion, as in (14):

The addition of the goal phrase makes the aspectual properties of those morphemes available for an endpoint reading (Aske [2]; Beavers et al. [3]). In fact, this applies to change-of-state events. The goal phrase functions as an accomplishment, indicating the result of an action, e.g. (15).

o

(15) a. Taroo ga chokkaku made kinzokuboo mage-ta.

Taroo NOM square until metal bar

ACC bend-PAST

'Taroo bent the metal bar to square.'

\subsection{Split Intransitivity Regarding the Postpositions}

The split further links the selection of postpositions (PPs). Below is a list of Japanese postpositions. Their scale property is given in (16).

(16) a. Totally open-scale morpheme: e 'toward'

b. Totally closed-scale morpheme: $n i$ 'to', made 'until'; ni sotte 'along'

c. Upper closed-scale morpheme: $e-t o^{3}$ 'towards' 'from'

d. Lower closed-scale morpheme: kara 'from'; yori

e. Non-scale change morpheme: unergative V, conveying the manner of motion

Recall the following ill-formed motion expression.

\section{*Taroo ga kooen ni aruita. \\ Taroo NOM park DAT walk PAST \\ 'Taroo walked to the park.'}

Japanese unergative verbs fail to combine with the PP $n i$. This is due to the following reasons: $n i$ is locative. Unergative verbs convey the manner of motion and therefore is unable to predicate a result location with the postpostion $n i$. $n i$ may perfectly well co-occur with an unaccusative verb, because an unaccusative verb denotes the path, therefore the PP can bear a directional interpretation.

The ungrammaticality of (17) can be improved by replacing $n i$ with $e$, which itself is a totally open-scale

$3 e$-to is between direction $e$ and delimitation made. postposition. With this $e$ in place, the motion expression changes the aspect from telic to atelic, c.f. (18):

\section{(18) Taroo ga kooen e aruita. \\ Taroo NOM park toward walk PAST \\ 'Taroo walked to the park.'}

(18) can also be improved by replacing $n i$ with an allative case marker made 'until', which is delimited and denotes an endpoint of motion. The scope of made includes the route and endpoint. On the other hand, $n i$ denotes a scope limited to the goal, as furnished by its appearance in locational motion events. Consequently, $n i$ tends to favour path verbs solely, such as tsuku 'arrive' and chakuriku suru 'land' (e.g. eki ni *aruita/tsuita), made is likely to occur with unergative verbs, such as aruku 'walk' as well as unaccusative verbs.

Furthermore, e-to, an upper-closed postposition, also appears compatible with unergative verbs, as in (19).

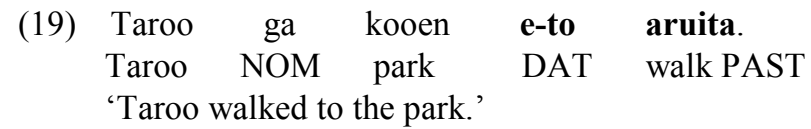

It seems that unaccusative verbs can well form a motion with all the postpositions in Japanese, i.e. $e$, e-to, and $n i$, as in (20):

(20) Taroo ga nikai e/ni/e-to agatta.

Taroo NOM upstairs DAT go up PAST

'Taroo went up to the second floor.'

Perhaps we can pause and draw a preliminary conclusion: unergative motion verbs such as aruku 'walk' and hashiru 'run' tend to describe processes with a durative motion event and are likely to yield directional PPs, e.g. $e$-to, $e$; or a route with an endpoint, e.g. made 'till'. On the other hand, unaccusative vers such as tsuku 'reach' or hairu 'enter' tend to indicate a punctual motion event and therefore often occur with locative PPs, e.g. ni. The foregoing discussion is summarised in Table 2:

Table 2. Split intransitivity in terms of postposition selections

\begin{tabular}{|c|c|c|}
\hline Scale structure & $\mathrm{P}$ & Intransitive V \\
\hline Totally open-scale & $e$ 'toward' & unaccusative \\
\hline Totally closed-scale & $n i$ 'to', made 'until' & unaccusative \\
\hline Upper closed-scale & e-to 'towards' & unaccusative \\
\hline Lower closed-scale & $\begin{array}{c}\text { kara 'from'; yori } \\
\text { 'from'; } \text { ni sotte } \\
\text { 'along' }\end{array}$ & unaccusative \\
\hline Non-scale change & & unergative \\
\hline
\end{tabular}

\section{Split Intransitivity in Mongolian}

\subsection{Mongolian Case System Regarding Motion}

Having drawn a picture of Japanese split intransitivity; 
we are in a better position to engage in the analysis of Mongolian data. Our starting point is the case selection in terms of motion event. Then, we will move on to the scale property of Mongolian motion verbs.

The Mongolian case system regarding motion event is as follows: Nominative Case, Accusative Case, Genitive Case, Dative-Locative Case, Ablative Case, Instrumental Case, Illative Case and Comitative Case. Table 3 provides a list of case particles with regard to motion in Mongolian and Japanese.

Table 3. Case particles in terms of motion in Mongolian and Japanese

\begin{tabular}{|c|c|c|}
\hline Case particle & Japanese & Mongolian \\
\hline Nominative & が $g a$ & $\varphi$ \\
\hline Accusative & を & -Ыг/-ийг/-г \\
\hline Genitive & の no & -ын/-ы/-ийн/-ий \\
\hline Dative & に $n i$ & -т/-д \\
\hline Ablative & で de & $-a a c^{4}$ \\
\hline Instrumental & で de & - aap $^{4}$ \\
\hline Illative & $\sim e$ & - pyy $^{2}$ \\
\hline Comitative & と to & -тай ${ }^{3}$ \\
\hline
\end{tabular}

\subsection{Split Intransitivity Regarding Motion Expression in Mongolian}

Mongolian case system distinguishes from Japanese case system in many respects, for instance, the manner of Mongolian motion verb yна takes an accusative case particle, e.g. -blг/-uйг/-z, while the corresponding manner verb in Japanese, i.e. noru takes the dative particle $n i$. The path of Mongolian motion verb чиглэ takes an accusative case particle, e.g. -blc/-uŭz/-z; while the corresponding path verb in Japanese mukau takes the dative particle $n i$. Some path verbs, such as явах 'go', caлax 'leave' take the instrumental particle $-a a p^{4}$. The path verb яваx 'go toward' takes an illative case particle, $-p y y^{2}$. Table 4 is a comparison of case selection in terms of motion in Japanese and Mongolian.

Table 4. The case system regarding motion construction in Japanese and Mongolian

\begin{tabular}{|c|c|c|}
\hline $\begin{array}{c}\text { Motion expression } \\
\text { (English translation) }\end{array}$ & Japanese & Mongolian \\
\hline (i) Cross the bridge. & Accusative & Instrumental \\
\hline (ii) Get off the bus. & Accusative & Ablative \\
\hline $\begin{array}{c}\text { (iii) Train stopped due } \\
\text { to heavy snow. }\end{array}$ & Instrumental & $\begin{array}{c}\text { Ablative, Dative, } \\
\text { Instrumental }\end{array}$ \\
\hline $\begin{array}{c}\text { (iv) Get out of a car. } \\
\text { home./Attend a } \\
\text { meeting }\end{array}$ & Ablative & Ablative \\
\hline $\begin{array}{c}\text { (vi) Drive toward } \\
\text { Tokyo }\end{array}$ & Dative & Dative \\
\hline $\begin{array}{c}\text { (vii) Go } \\
\text { shopping./Come to see } \\
\text { me. }\end{array}$ & Dative & Dative \\
\hline
\end{tabular}

This study gives a partial list of mostly used unaccusative verbs and unergative verbs. Based upon scale structure, they are classified into five variations:

(21) a. Totally open-scale morphemes:

явах 'pass through'

зайлах 'ward off'

явах 'go toward'

үл ойшоох 'go against'

шилжүүлэн 'slip out'

उөөх 'shift'

явах 'ply'

зэрэгцүүлэх 'queue up'

эргэхmawaru 'around'

b. Totally closed-scale morphemes:
ирэх 'arrive'
хүрэх 'get to'
дамжуулах 'reach'
мордох 'get on'
давах 'transcend'
гарах 'get down'
тоолох 'through'
дэргэдүүр 'past'
огтлох $u$ 'cross'
гарах 'exit'
орох 'entre'

c. Upper closed-scale morphemes: буцах 'return' ирэх 'come' гарах 'cross' харих 'return' өнгөрөх 'pass' оиргон 'approach' бyyx 'descend' гарах 'climb'

d. Lower closed-scale morphemes: тойрох 'move around' явах 'go' мөрдөх 'go along' оиртох 'approach' салах 'leave' yxpax 'move backward' булаах 'flit' мордох 'go away' буyx 'descend' rapax 'ascend'

e. Non-scale change morphemes: явган явах 'walk' алхах 'walk' усанд сэлэх 'swim' драйв 'run' гүйх 'run' мөлхөх 'crawl' гулгах 'slide' бүжиглэх 'dance' гүйлгэх 'tumble' 


$$
\begin{aligned}
& \text { харайх ‘jump' } \\
& \text { намалзах 'dance' } \\
& \text { шургалан opox 'dive' } \\
& \text { эргэлжэх 'wander' } \\
& \text { нисэх 'fly' }
\end{aligned}
$$

The distribution of split intransitivity is as follows.

(22) a. Non-scale change morpheme: unergative V, conveying the manner of motion

b. Totally open-scale morpheme: unergative $\mathrm{V}$, denoting the manner of motion

c. Totally closed-scale morpheme: unaccusative V, denoting the path of motion

d. Upper closed-scale morpheme: unaccusative $\mathrm{V}$, denoting the path of motion

e. Lower closed-scale morpheme: unaccusative

$\mathrm{V}$, denoting the path of motion

(23) illustrates two motion expressions in Mongolian.

$$
\begin{array}{ccc}
\text { (23) a. Япон } & \text { pyy } & \text { явах } \\
\text { Japan Illative } & \text { go. } \\
\text { 'Go to Japan.' } &
\end{array}
$$

\section{b. Улаангом оос ирсэн. Улаангом Ablative come-PAST 'I came from Улаангом.'}

Mongolian tends to lexicalises the path in the main verb, leaving manner to be encoded in an optional constituent, as in (24), where the core of the motion expression is rendered by verb zapax 'climb'; the manner of motion is expressed by a converbal construction.

$$
\begin{array}{ll}
\text { (24) дээр } & \text { гарах } \\
\text { upwards } & \text { climb }
\end{array}
$$

There are two variations in regard to expressing manner of motion: (i) coordinate relation of Manner and Path. (ii) accompanying Manner + Path. (25) provides the illustrations.

\section{(25) Motion expression with Manner and Path}

a. Coordinate relation

эргэн -гүйх 'run about'

тойрон - Гүйх 'run about'

\section{b. Accompanying Manner + Path}

$$
\text { сэмэрхэн - ойртох 'crawl towards' }
$$$$
\text { бүдэрэн - унах 'tumble-fall' }
$$

Essentially, the combination of converbal construction is not arbitrary, but restricted to the order of [Non-scale change morphemes + totally closed-scale change morphemes] or [Non-scale change morphemes + Lower closed-scale morphemes]. That is, the second constituent has to be a closed-scale change morpheme. This rule applies not only to motion event but also change-of-state event.

\section{Summary}

There are variations in split intransitivity even within the same language family, i.e. Japanese and Mongolian. This paper conducted a comparison of the two languages based upon the mereological framework: scale structure. The finding brings us to the point that intransitives split in lexicalisation of motion events as well as postposition selections. Mongolian tends to lexicalises the path in the main verb, leaving manner to be encoded in an optional constituent, i.e. a converbal construction. Japanese unergative verbs tend to yield the MANNER of motion while unaccusative verbs tend to convey the PATH of motion. Furthermore, unergative motion verbs tend to describe processes with a durative motion event and are likely to yield directional PPs. On the other hand, unaccusative verbs tend to indicate a punctual motion event and therefore often occur with locative PPs. This is a preliminary work that inspires us to explore the phenomenon of split intransitivity regarding Altaic language in more depth.

\begin{tabular}{|c|c|c|c|c|c|c|c|c|c|c|c|}
\hline a $a$ & $6 b$ & в $v$ & $\Gamma g$ & д $d$ & e ye & ë yo & жj & $3 d z$ & и $i$ & й $y$ & к $k$ \\
\hline л $l$ & м $m$ & н $n$ & o $O$ & ө $\ddot{O}$ & $\Pi p$ & $\mathrm{p} r$ & $\mathrm{c} s$ & $\mathrm{~T} t$ & у $u$ & Ү $\ddot{u}$ & $\phi f$ \\
\hline $\mathrm{x} k h$ & ц $t s$ & ч $c h$ & ш $s h$ & щ shch & ъ ” & ы $i$ & $\mathbf{b}^{\prime}$ & э $e$ & ю $y u$ & я ya & \\
\hline
\end{tabular}

\section{Acknowledgements}

This paper is based upon work supported by National Foundation of Social Sciences (15CYY002) China, and Qianjiang Talent Programme of Zhejiang Province, China (QJC1402005: 2014-2017) to Wenchao Li. I would like to thank the anonymous reviewers for their comments, which have helped me sharpen and develop the manuscript a great deal. All remaining errors and shortcomings are entirely mine.

\section{Mongolian Cyrillic alphabet}




\section{REFERENCES}

[1] Arad, Maya. VP-structure and the syntax-lexicon interface. MIT Occasional Paper in Linguistics 16. 1998a.

[2] Aske, John. Path predicates in English and Spanish: a closer look. In Kira Hall, Michael Meacham \& Richard Shapiro (eds.), Proceedings of the Fifteenth Annual Meeting of the Berkeley Linguistics Society (1-14). Berkeley: Berkeley Linguistics Society. 1989.

[3] Beavers, John. The structure of lexical meaning: Why semantics really matters. Language 86: 821- 864. 2010.

[4] Bolinger, Dwight. Degree Words. The Hague: Mouton. 1972

[5] Borer, Hagit. The projection of arguments. In E. Benedicto and J. Runner (eds.) Functional Projections. University of Massachusetts, Amherst: Occasional Papers 17. 19-47. 1994.

[6] Dowty, D. Thematic proto-roles and argument selection. Language 67 (3), 547-619. 1991.

[7] Géraldine Legendre and Antonella Sorace. Split intransitivity in French: an optimality-theoretic perspective. PaperpresentedatPennStateuniversity.OnlineAvailable:http:// citeseerx.ist.psu.edu/viewdoc/download?doi=10.1.1.466.502 $4 \&$ rep $=$ rep $1 \&$ type $=$ pdf

[8] Hay, Jennifer, Christopher Kennedy, and Beth Levin. Scalar structure underlies telicity in 'degree achievements'. Semantics and Linguistic Theory 9, 127-144. 1999.

[9] Kageyama, Taro. Doushiimiron-gengo to ninchi no setten. Kuroshio. 1996.

[10] Ken Hale and Jay Keyser. Some transitivity alternations in English. Lexical Project Working Paper 7, Centre for Cognitive Science, MIT. 1986.

[11] Ken Hale and Jay Keyser. On argument structure and the lexical representation of syntactic relations. In K. Hale and J. Keyser (eds.), The View from Building 20, pp 53-109. MIT Press, Cambridge, MA. 1993.

[12] Kennedy, Christopher. Projecting the Adjectives: The Syntax and Semantics of Gradability and Comparison. New York: Garland. 1999.

[13] Kennedy, Christopher and Beth Levin. Measure of Change: The Adjectival Core of Degree Achievements. In L. McNally and C. Kennedy (ed.). Adjectives and Adverbs:
Syntax, Semantics and Discourse. Oxford, UK: Oxford University Press, 156-182. 2008.

[14] Kennedy, Christopher and Louise McNally. Scale structure, degree modification, and the semantics of gradable predicates. Language 81. 2, 345-381. 2005.

[15] Legendre, G. On the typology of auxiliary selection. Lingua 117 (9), 1522-1540. 2007a.

[16] Legendre, G. Optimizing auxiliary selection in romance. In R. Aronovich (Ed.), Split Auxiliary Systems: A Cross-linguistic Perspective. John Benjamins: John Benjamins. 2007b.

[17] Levin, Beth and Rappaport Hovav, Malka. The lexical semantics of verbs of motion: The perspective from unaccusativity. In Iggy Roca (Ed.) Thematic Structure: Its Role in Grammar. Dordrecht: Foris, 247-269. 1992.

[18] Levin, Beth and Rappaport Hovav, Malka. A preliminary analysis of causative verbs in English. Lingua 92: 35-77. 1994.

[19] Levin, Beth and Rappaport Hovav, Malka. Unaccusativity: At the Syntax-Semantics Interface. Cambridge, MA: MIT Press. 1995.

[20] Levin, B. \& M. Rappaport Hovav. Lexicalized scales and verbs of scalar change. Paper presented at the CLS 46. 2010.

[21] McClure, William. Syntactic Projections of the Semantic of Aspect. Tokyo: Hitsujishobo. 1995.

[22] Perlmutter, David. Mutiattachment and the Unaccusative Hypothesis: The perfect auxiliary in Italian. Probus: Journal of Latin and Romance Linguistics, 1: 63-120. 1989.

[23] Perlmutter, D.M. and P.M. Postal. "The 1-Advancement Exclusiveness Law", in D.M. Perlmutter and C. Rosen, eds., (1984) Studies in Relational Grammar 2, University of Chicago Press, Chicago, IL, 81-125. 1984.

[24] Sapir, Edward. Grading: a study in semantics. Philosophy of Science (11): 93-116. 1944.

[25] Sorace, A. Gradients in auxiliary selection with intransitive verbs. Language 76 (4), 859-890. 2000.

[26] van Hout, Angeliek. Event Semantics of Verb Frame Alternations. A Case Study of Dutch and Its Acquisition. Tilburg: University of Tilburg. 1996. van Hout, Angeliek. Event semantics in the lexicon-syntax interface: Verb frame alternations in Dutch and their acquisition'. In C. Tenny \& J. Pustejovsky (Eds.), Events as grammatical objects, 239-282. CSLI, Stanford. 2000. 